\title{
9. X-RAY MINERALOGY OF CORES FROM LEG 40, DEEP SEA DRILLING PROJECT
}

\author{
W.G. Siesser, Department of Geology, University of Cape Town \\ and \\ J.M. Bremner, National Research Institute for Oceanology, Stellenbosch
}

\section{INTRODUCTION}

Sedimentologists on Leg 40 selected representative samples from each hole for X-ray diffraction analysis. The purpose of this X-ray study is to provide basic data on the bulk mineralogy and to identify certain components not readily identifiable by optical methods (e.g., zeolites and clays). Certain mineralogic trends noted in the cores are discussed in a later section.

The X-ray mineralogy laboratory at Riverside, California, has developed a "minlog" program which produces semiquantitative values for various mineral components in DSDP sediments. We have thus presented the data in Tables 1-6 in a manner which can be modified and used for minlog computation. The tables also list the lithologic unit assigned to the sediments in Chapters 2-4 of this volume and the type of sediment analyzed.

\section{ANALYTICAL METHODS}

Samples were first dialysed for $24 \mathrm{hr}$ in fresh water to remove interstitial salt. Each sample was then split into two halves, one portion being used for a briquette mount (for bulk analysis), the other for a glass-slide mount (for clay analysis).

The split intended for bulk analysis was dried, then crushed in an automatic pestle and mortar. Two grams of the crushed sediment were pressed into a bakelitebacked briquette in order to obtain X-ray results with maximum reproducibility. Each briquette was pressed for $1 \mathrm{~min}$ at 2100 bars pressure.

Splits destined for clay-mineral analysis were pretreated prior to slide preparation. The carbonate was first removed with $25 \% \mathrm{CH}_{3} \mathrm{COOH}$. The clays were then saturated with magnesium for $4 \mathrm{hr}$ in a $1 \mathrm{~N} \mathrm{MgCl}_{2}$ solution to ensure uniform expansion after glycolation. Preferred-orientation mounts (glass slides) were made from this suspension, then dried immediately in a warm oven to minimize differential settling. The slides were next fumed with ethylene glycol for $48 \mathrm{hr}$ in a desiccator at a constant temperature of $70^{\circ} \mathrm{C}$, then X-rayed. If the diffractogram suggested that chlorite might be present, a second, unglycolated, slide was prepared. These slides were heated at $550^{\circ} \mathrm{C}$ for $1 \mathrm{hr}$ in an electric furnace and $\mathrm{X}$-rayed as soon as they were cool.

Samples were run on a Phillips PW 1540 X-ray diffractometer using $\mathrm{Ni}$-filtered $\mathrm{CuK} \alpha$ radiation. Briquettes were scanned from $3^{\circ}$ to $58^{\circ} 2 \theta$ and glass slides from $3^{\circ}$ to $13^{\circ} 2 \theta$ at a speed of $1^{\circ} 2 \theta$ per minute. Instrument settings were as follows:
$\mathrm{Kv} / \mathrm{mA}-48 / 20$

Rate meter-4 $4 \times 10^{2}$ (briquettes), $1 \times 10^{3}$ (glass slides)

Time constant -4 Window-250-100-1

Slits $-1^{\circ} / .1 / 1^{\circ}$

Attenuation-2(briquettes), 3(glass slides).

Proportional counter-455

All mineral identifications were made visually, after which a baseline was constructed by manually drawing a line tangent to the background trace. A numerical value is given for each mineral detected (Tables 1-6). This number represents the peak-height intensity for maxima centered at the following d-spacings:

$\begin{array}{lc}\text { Mineral } & \text { d-spacing }(\AA) \\ \text { Calcite } & 3.035 \\ \text { Dolomite } & 2.886 \\ \text { Quartz } & 3.343 \\ \text { K-feldspar } & 3.24 \\ \text { Plagioclase } & 3.18 \\ \text { Pyrite } & 1.633 \\ \text { Phillipsite } & 4.97 \\ \text { Harmotome } & 3.12 \\ \text { Clinoptilolite } & 9.00 \\ \text { Kaolinite } & 7.15 \\ \text { "Illite" } & 10.00 \\ \text { Montmorillonite } & 17.0-18.0 \\ \text { Chlorite } & 14.0\end{array}$

It should be noted that the relative intensities reported for clay minerals cannot be directly compared with the intensities of the other minerals. The clay intensities were measured on carbonate-free preparations whereas the other intensities were measured on bulk-analysis preparations.

\section{DRILLING MUD USAGE}

Unweighted drilling mud was used at all sites other than 361 . Nevertheless, barite was not detectable by Xray in any samples from Site 361, indicating that contamination is unlikely. Bentonitic drilling mud was used in flushes at Sites 361, 363, 364, and 365. Samples from core intervals which could conceivably have been contaminated contain only normal amounts of montmorillonite, or in some cases, no montmorillonite at all, again suggesting that contamination is unlikely.

\section{CLAY MINERALOGY}

Clay minerals detected belong to four groups: kaolinite, mica ("illite"), montmorillonite, and chlorite. In addition, mixed-layer clay minerals were noted in almost all the samples investigated. No palygorskite was detected. 
TABLE 1

Mineralogical Results From Site 360

\begin{tabular}{|c|c|c|c|c|c|c|c|c|c|c|c|c|c|c|c|c|c|c|c|}
\hline \multirow{2}{*}{$\begin{array}{l}\text { Sample } \\
\text { (Interval } \\
\text { in } \mathrm{cm} \text { ) }\end{array}$} & \multirow[b]{2}{*}{ Unit } & \multirow{2}{*}{$\begin{array}{l}\text { Sediment } \\
\text { Type }\end{array}$} & \multicolumn{9}{|c|}{ Peak-Height Intensities } & \multicolumn{4}{|c|}{ Peak-Height Intensities } & \multicolumn{3}{|c|}{ Relative \% } & \multirow{2}{*}{$\begin{array}{l}\text { Unidentified } \\
\text { Peaks }\end{array}$} \\
\hline & & & Calc & Dolo & $\mathrm{Qz}$ & K-Feld & Plag & Pyr & Phil & Harm & Clino & $\mathrm{Kao}$ & III & Mont & $\mathrm{Chl}$ & $\mathrm{KaO}$ & III & Mont & \\
\hline $1-3,68-70$ & 1 & $\begin{array}{l}\text { Foram-nanno } \\
\text { ooze }\end{array}$ & 240 & 0 & 15 & 0 & 2 & 0 & $\mathrm{t}$ & 0 & 0 & 7 & 22 & 8 & 0 & 10 & 84 & 6 & \\
\hline $3-3,68-70$ & 1 & $\begin{array}{l}\text { Nannofossil } \\
\text { ooze }\end{array}$ & 194 & 0 & 16 & 3 & 0 & 0 & 2 & 0 & 0 & 10 & 22 & 8 & 0 & 20 & 74 & 6 & \\
\hline $6-3,68-70$ & 1 & $\begin{array}{l}\text { Nannofossil } \\
\text { ooze }\end{array}$ & 220 & 0 & 16 & 0 & 3 & 0 & $\mathrm{t}$ & 0 & 0 & 7 & 23 & 0 & 10 & 7 & 93 & 0 & \\
\hline $11-3,68-70$ & 1 & $\begin{array}{l}\text { Nannofossil } \\
\text { ooze }\end{array}$ & 208 & 0 & 22 & 0 & 3 & 0 & $\mathrm{t}$ & 0 & 0 & 10 & 23 & 10 & 11 & 15 & 79 & 6 & \\
\hline $14-3,68-70$ & 2 & $\begin{array}{l}\text { Nannofossil } \\
\text { chalk }\end{array}$ & 140 & 0 & 40 & 9 & 0 & 0 & $\mathrm{t}$ & 0 & 0 & 4 & 19 & 10 & 0 & 4 & 88 & 8 & \\
\hline $17-3,68-70$ & 2 & $\begin{array}{l}\text { Nannofossil } \\
\text { chalk }\end{array}$ & 200 & 0 & 23 & 0 & 3 & 0 & $\mathrm{t}$ & 0 & 0 & 7 & 35 & 9 & 11 & 11 & 83 & 6 & \\
\hline $20-3,68-70$ & 2 & $\begin{array}{l}\text { Nannofossil } \\
\text { chalk }\end{array}$ & 203 & 0 & 13 & 0 & 2 & 0 & 3 & 0 & 0 & 8 & 22 & 9 & 0 & 16 & 75 & 9 & \\
\hline $23-3,68-70$ & 2 & $\begin{array}{l}\text { Nannofossil } \\
\text { chalk }\end{array}$ & 190 & 0 & 23 & 0 & 48 & 0 & $t$ & 0 & 0 & 6 & 15 & 8 & 0 & 11 & 82 & 7 & \\
\hline $25-1,68-70$ & 2 & $\begin{array}{l}\text { Nannofossil } \\
\text { chalk }\end{array}$ & 190 & 0 & 6 & 0 & 9 & 0 & $\mathrm{t}$ & 0 & 0 & 7 & 21 & 15 & 12 & 9 & 77 & 14 & \\
\hline $27-3,65-67$ & 3 & $\begin{array}{l}\text { Nannofossil } \\
\text { chalk }\end{array}$ & 197 & 0 & 9 & 0 & 0 & 0 & t & 0 & 0 & 8 & 19 & 12 & 8 & 11 & 76 & 13 & \\
\hline $30-3,68-70$ & 3 & $\begin{array}{l}\text { Nannofossil } \\
\text { chalk }\end{array}$ & 207 & 0 & 15 & 0 & 3 & 0 & 1 & 0 & 0 & 6 & 11 & 17 & 0 & 13 & 42 & 45 & \\
\hline $33-3,68-70$ & 3 & $\begin{array}{l}\text { Marly nanno- } \\
\text { fossil chalk }\end{array}$ & 190 & 0 & 24 & 0 & 4 & 0 & $\mathrm{t}$ & 0 & 0 & 6 & 15 & 18 & 0 & 9 & 60 & 31 & \\
\hline $36-3,68-70$ & 4 & $\begin{array}{l}\text { Marly nanno- } \\
\text { fossil chalk }\end{array}$ & 175 & 0 & 23 & 0 & 3 & 0 & $\mathrm{t}$ & 0 & 0 & 5 & 15 & 20 & 0 & 7 & 58 & 35 & \\
\hline $40-2,65-68$ & 4 & $\begin{array}{l}\text { Marly nanno- } \\
\text { fossil chalk }\end{array}$ & 90 & 0 & 25 & 6 & 6 & 0 & 0 & 0 & 0 & 0 & 12 & 13 & 0 & 0 & 79 & 21 & \\
\hline $43-2,68-70$ & 4 & $\begin{array}{l}\text { Marly nanno- } \\
\text { fossil chalk }\end{array}$ & 81 & 0 & 22 & 3 & 6 & 0 & 0 & 0 & 0 & 0 & 14 & 22 & 0 & 0 & 81 & 19 & $4.11 \AA$ \\
\hline $46-3,68-70$ & 4 & $\begin{array}{l}\text { Calcareous } \\
\text { claystone }\end{array}$ & 45 & 0 & 33 & 5 & 6 & 0 & $\mathrm{t}$ & 0 & 0 & 3 & 13 & 21 & 0 & 2 & 70 & 28 & $3.52 \AA$ \\
\hline $50-1,68-70$ & 4 & $\begin{array}{l}\text { Calcareous } \\
\text { claystone }\end{array}$ & 53 & 0 & 30 & 4 & 4 & 0 & $t$ & 0 & 0 & 3 & 16 & 18 & 0 & 2 & 70 & 28 & \\
\hline
\end{tabular}


TABLE 2

Mineralogical Results From Site 361

\begin{tabular}{|c|c|c|c|c|c|c|c|c|c|c|c|c|c|c|c|c|c|c|c|}
\hline \multirow{2}{*}{$\begin{array}{l}\text { Sample } \\
\text { (Interval } \\
\text { in cm) }\end{array}$} & \multirow[b]{2}{*}{ Unit } & \multirow[b]{2}{*}{ Sediment Type } & \multicolumn{9}{|c|}{ Peak-Height Intensities } & \multicolumn{4}{|c|}{ Peak-Height Intensities } & \multicolumn{3}{|c|}{ Relative \% } & \multirow{2}{*}{$\begin{array}{l}\text { Unidentified } \\
\text { Peaks }\end{array}$} \\
\hline & & & Calc & Dolo & $\mathrm{Qz}$ & K-Feld & Plag & Pyr & Phil & Harm & Clino & Kao & III & Mont & Chl & Kao & III & Mont & \\
\hline $1-2,68-72$ & $4 \mathrm{~A}$ & Mud & 5 & 0 & 71 & 20 & 22 & 0 & 0 & 3 & 0 & 3 & 3 & 4 & 8 & 21 & 63 & 3 & \\
\hline $2-2,68-70$ & $4 \mathrm{~A}$ & Mud & 0 & 0 & 77 & 23 & 26 & 0 & 0 & 0 & 0 & 2 & 15 & 8 & 0 & 2 & 88 & 10 & \\
\hline $3-1,63-65$ & $4 \mathrm{~A}$ & Mud & 0 & 0 & 95 & 15 & 35 & 0 & 0 & 0 & 0 & 2 & 24 & 8 & 10 & 2 & 88 & 10 & \\
\hline $5-4,68-70$ & $4 \mathrm{~A}$ & $\begin{array}{l}\text { Marly nanno- } \\
\text { fossil ooze }\end{array}$ & 48 & 0 & 63 & 11 & 10 & 0 & 0 & 0 & 0 & 4 & 8 & 13 & 15 & 7 & 62 & 31 & \\
\hline $6-2,68-70$ & $4 \mathrm{~A}$ & $\begin{array}{l}\text { Marly nanno- } \\
\text { fossil ooze }\end{array}$ & 18 & 0 & 115 & 15 & 26 & 0 & 0 & 0 & 0 & 0 & 32 & 22 & 0 & 0 & 85 & 15 & \\
\hline $8-6,73-75$ & $4 \mathrm{~A}$ & $\begin{array}{l}\text { Marly nanno- } \\
\text { fossil chalk }\end{array}$ & 98 & 0 & 7 & 0 & 2 & 0 & $\mathrm{t}$ & 0 & 0 & 8 & 20 & 51 & 0 & 4 & 31 & 65 & \\
\hline $10-3,68-70$ & 5 & $\begin{array}{l}\text { Brown } \\
\text { pelagic clay }\end{array}$ & 0 & 2 & 36 & 11 & 8 & 0 & $\mathrm{t}$ & 0 & 0 & 8 & 16 & 23 & 0 & 12 & 44 & 44 & \\
\hline $11-3,68-70$ & 5 & $\begin{array}{l}\text { Brown } \\
\text { pelagic clay }\end{array}$ & 0 & 2 & 46 & 11 & 10 & 0 & 1 & 0 & 0 & 6 & 24 & 19 & 18 & 6 & 74 & 20 & \\
\hline $15-2,48-50$ & 6 & $\begin{array}{l}\text { Grayish sandy } \\
\text { mudstone }\end{array}$ & 0 & 0 & 98 & 48 & 40 & 2 & 0 & 0 & 0 & 0 & 12 & 5 & 0 & 0 & 96 & 4 & \\
\hline $19-3,67-70$ & 6 & $\begin{array}{l}\text { Grayish sandy } \\
\text { mudstone }\end{array}$ & 0 & 0 & 52 & 8 & 84 & 0 & $\mathrm{t}$ & 0 & 0 & 6 & 9 & 15 & 15 & 13 & 52 & 35 & \\
\hline $26-3,125-127$ & 6 & $\begin{array}{l}\text { Dusky red } \\
\text { claystone }\end{array}$ & 35 & 0 & 71 & 8 & 12 & 0 & 7 & 0 & 0 & 2 & 15 & 9 & 0 & 3 & 80 & 17 & \\
\hline $30-3,98-100$ & 7 & $\begin{array}{l}\text { Carbonaceous } \\
\text { sandy mudstone }\end{array}$ & 0 & 0 & 133 & 11 & 17 & 4 & 7 & 0 & 0 & 3 & 3 & 0 & 0 & 39 & 61 & 0 & \\
\hline $32-3,68-70$ & 7 & $\begin{array}{l}\text { Carbonaceous } \\
\text { sandy mudstone }\end{array}$ & 0 & 0 & 126 & 25 & 19 & 1 & 8 & 0 & 0 & 8 & 15 & 0 & 0 & 11 & 89 & 0 & \\
\hline $34-3,104-106$ & 7 & $\begin{array}{l}\text { Carbonaceous } \\
\text { shale }\end{array}$ & 13 & 0 & 135 & 21 & 33 & 5 & $t$ & 0 & 0 & 7 & 3 & 0 & 0 & 52 & 48 & 0 & \\
\hline $38-3,77-79$ & 7 & $\begin{array}{l}\text { Carbonaceous } \\
\text { sandy siltstone }\end{array}$ & 0 & 125 & 114 & 29 & 19 & 0 & 0 & 0 & 0 & 7 & 10 & 0 & 4 & 18 & 82 & 0 & \\
\hline $40-3,70-72$ & 7 & $\begin{array}{l}\text { Carbonaceous } \\
\text { silty shale }\end{array}$ & 0 & 3 & 131 & 16 & 19 & 3 & $\mathrm{t}$ & 0 & 0 & 14 & 16 & 0 & 0 & 16 & 84 & 0 & \\
\hline $42-1,67-70$ & 7 & $\begin{array}{l}\text { Carbonaceous } \\
\text { Shale }\end{array}$ & 15 & 0 & 72 & 0 & 5 & 9 & $\mathrm{t}$ & 9 & 0 & 5 & 5 & 0 & 3 & 36 & 64 & 0 & \\
\hline $44-3,58-70$ & 7 & $\begin{array}{l}\text { Carbonaceous } \\
\text { sandy mudstone }\end{array}$ & 0 & 0 & 135 & 49 & 27 & 0 & 5 & 0 & 0 & 24 & 10 & 0 & 0 & 56 & 44 & 0 & \\
\hline $46-2,86-88$ & 7 & $\begin{array}{l}\text { Carbonaceous } \\
\text { sandy mudstone }\end{array}$ & 0 & 0 & 129 & 23 & 29 & 0 & 5 & 0 & 0 & 15 & 12 & 0 & 0 & 28 & 72 & 0 & \\
\hline $48-1,81-83$ & 7 & $\begin{array}{l}\text { Carbonaceous } \\
\text { calcite-cemented } \\
\text { sandstone }\end{array}$ & 263 & 0 & 144 & 12 & 16 & 0 & 4 & 0 & 0 & 7 & 12 & 3 & 0 & 13 & 85 & 2 & \\
\hline
\end{tabular}


TABLE 3

Mineralogical Results From Site 362

\begin{tabular}{|c|c|c|c|c|c|c|c|c|c|c|c|c|c|c|c|c|c|c|c|}
\hline \multirow{2}{*}{$\begin{array}{c}\text { Sample } \\
\text { (Interval in } \mathrm{cm} \text { ) }\end{array}$} & \multirow[b]{2}{*}{ Unit } & \multirow[b]{2}{*}{ Sediment Type } & \multicolumn{9}{|c|}{ Peak-Height Intensities } & \multicolumn{4}{|c|}{ Peak-Height Intensities } & \multicolumn{3}{|c|}{ Relative \% } & \multirow{2}{*}{$\begin{array}{l}\text { Unidentified } \\
\text { Peaks }\end{array}$} \\
\hline & & & Calc & Dolo & $\mathrm{Qz}$ & K-Feld & Plag & Pyr & Phil & Harm & Clino & Kao & Ill & Mont & Chl & Kao & Ill & Mont & \\
\hline $1-4,69-71$ & $1 \mathrm{~A}$ & $\begin{array}{l}\text { Siliceous nanno- } \\
\text { fossil ooze }\end{array}$ & 152 & 1 & 22 & 0 & 7 & 0 & 3 & 0 & $\mathrm{t}$ & 7 & 20 & 8 & 14 & 14 & 78 & 8 & \\
\hline $3-3,68-70$ & $1 \mathrm{~A}$ & $\begin{array}{l}\text { Marly nanno- } \\
\text { fossil ooze }\end{array}$ & 158 & 0 & 27 & 0 & 6 & 0 & $\mathrm{t}$ & 0 & 0 & 3 & 14 & 0 & 8 & 7 & 93 & 0 & \\
\hline $5-3,68-70$ & $1 \mathrm{~A}$ & $\begin{array}{l}\text { Diatomaceous } \\
\text { mud }\end{array}$ & 85 & 0 & 24 & 3 & 5 & 2 & $\mathrm{t}$ & 0 & 0 & 3 & 7 & 0 & 0 & 18 & 82 & 0 & \\
\hline $18-3,68-70$ & $2 \mathrm{~A}$ & $\begin{array}{l}\text { Siliceous nanno- } \\
\text { fossil chalk }\end{array}$ & 145 & 0 & 22 & 0 & 4 & 0 & $\mathrm{t}$ & 2 & 0 & 7 & 23 & 9 & 11 & 9 & 81 & 9 & \\
\hline $25-3,68-70$ & $2 \mathrm{~A}$ & $\begin{array}{l}\text { Marly nanno- } \\
\text { fossil chalk }\end{array}$ & 200 & 6 & 12 & 0 & 1 & 0 & $\mathrm{t}$ & 0 & 0 & 7 & 22 & 11 & 12 & 14 & 71 & 14 & \\
\hline $35-3,68-70$ & $2 \mathrm{~B}$ & $\begin{array}{l}\text { Marly nanno- } \\
\text { fossil chalk }\end{array}$ & 160 & 0 & 19 & 3 & 0 & 0 & $\mathrm{t}$ & 0 & 0 & 8 & 27 & 19 & 22 & 6 & 77 & 17 & \\
\hline $38-3,88-90$ & $2 \mathrm{C}$ & $\begin{array}{l}\text { Marly nanno- } \\
\text { fossil chalk }\end{array}$ & 170 & 0 & 13 & 0 & 0 & 0 & 0 & 0 & 0 & 10 & 23 & 15 & 26 & 12 & 72 & 15 & \\
\hline $3 A-3,68-70$ & $2 \mathrm{C}$ & $\begin{array}{l}\text { Marly nanno- } \\
\text { fossil chalk }\end{array}$ & 137 & 0 & 27 & 3 & 5 & 0 & 3 & 0 & 0 & 8 & 22 & 13 & 17 & 8 & 79 & 13 & \\
\hline $4 A-3,63-65$ & 3 & $\begin{array}{l}\text { Marly nanno- } \\
\text { fossil chalk }\end{array}$ & 145 & 0 & 21 & 0 & 7 & 0 & 0 & 0 & 0 & 5 & 20 & 16 & 26 & 5 & 76 & 19 & \\
\hline $5 A-3,64-56$ & 3 & $\begin{array}{l}\text { Braarudosphaera } \\
\text { chalk }\end{array}$ & 425 & 7 & 10 & 0 & 0 & 0 & 0 & 0 & 0 & 8 & 23 & 20 & 22 & 18 & 82 & 0 & \\
\hline $8 \mathrm{~A}-3,99-101$ & 4 & Marly limestone & 200 & 0 & 11 & 0 & 2 & 0 & 2 & 0 & 0 & 4 & 19 & 12 & 10 & 9 & 68 & 23 & \\
\hline $9 \mathrm{~A}-3,103-105$ & 4 & Marly limestone & 228 & 0 & 9 & 0 & 0 & 0 & 2 & 0 & $\mathrm{t}$ & 5 & 19 & 21 & 0 & 4 & 63 & 33 & \\
\hline $10 \mathrm{~A}-3,118-120$ & 4 & Marly limestone & 125 & 0 & 12 & 0 & 0 & 0 & 2 & 2 & 0 & 3 & 19 & 17 & 0 & 2 & 77 & 21 & \\
\hline
\end{tabular}

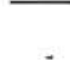


TABLE 4

Mineralogical Results From Site 363

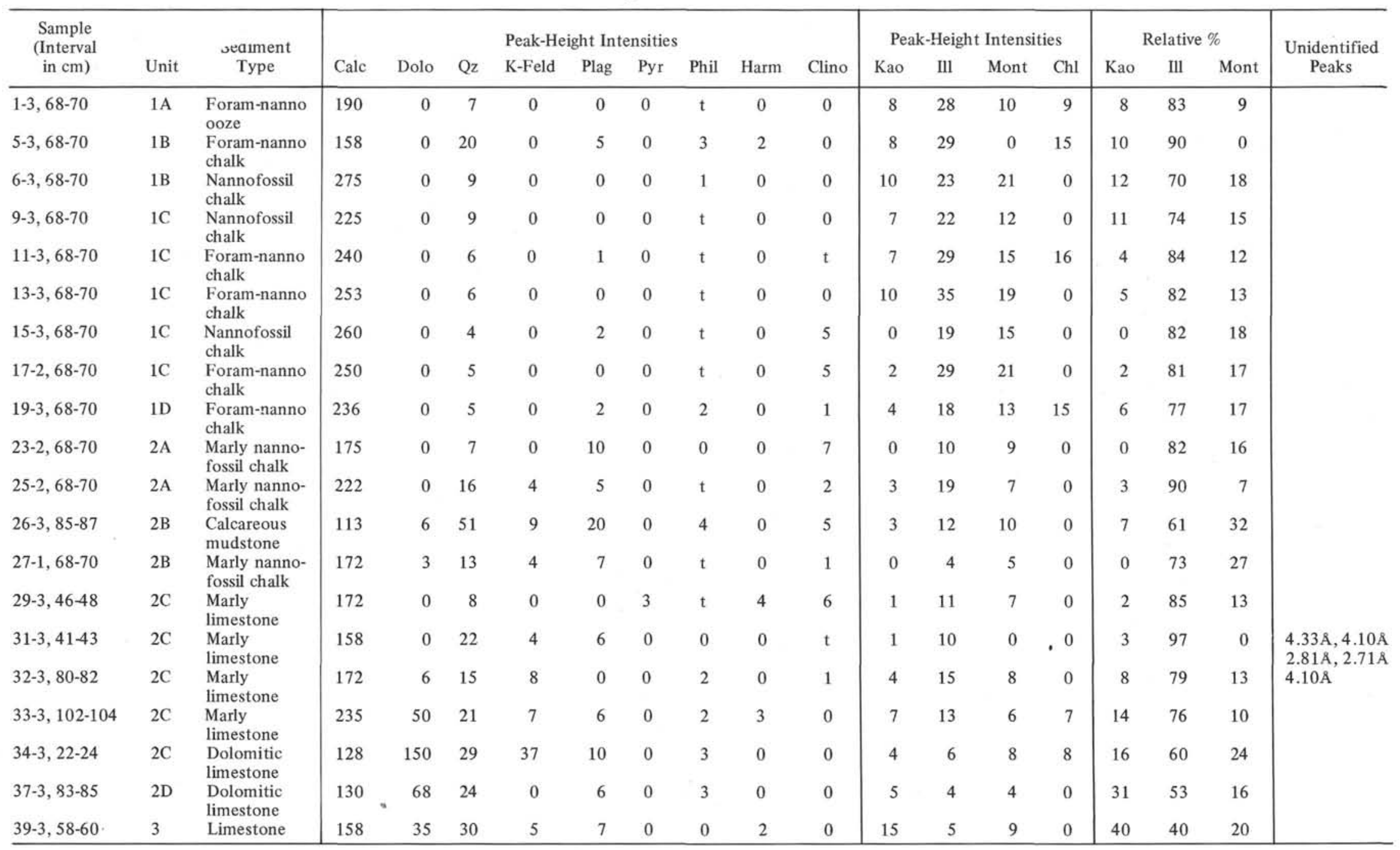




\begin{tabular}{|c|c|c|c|c|c|c|c|c|c|c|c|c|c|c|c|c|c|c|c|}
\hline \multirow{2}{*}{$\begin{array}{c}\text { Sample } \\
\text { (Interval } \\
\text { in } \mathrm{cm} \text { ) }\end{array}$} & \multirow[b]{2}{*}{ Unit } & \multirow[b]{2}{*}{ Sediment Types } & \multirow[b]{2}{*}{ Calc } & \multirow[b]{2}{*}{ Dolo } & \multirow[b]{2}{*}{$\mathrm{Qz}$} & \multicolumn{3}{|c|}{ Peak-Height Intensities } & \multirow[b]{2}{*}{ Phil } & \multirow[b]{2}{*}{ Harm } & \multirow[b]{2}{*}{ Clino } & \multicolumn{4}{|c|}{ Peak-Height Intensities } & \multicolumn{3}{|c|}{ Relative \% } & \multirow{2}{*}{$\begin{array}{l}\text { Unidentified } \\
\text { Peaks }\end{array}$} \\
\hline & & & & & & K-Feld & Plag & Pyr & & & & Kao & III & Mont & Chl & Kao & III & Mont & \\
\hline $1-3,68-70$ & 1 & Calcareous mud & 19 & 0 & 37 & 7 & 8 & 0 & 4 & 0 & 0 & 38 & 23 & 21 & 0 & 43 & 34 & 23 & \\
\hline $3-3,68-70$ & 2 & $\begin{array}{l}\text { Marly nannofossil } \\
\text { ooze }\end{array}$ & 94 & 0 & 28 & 0 & 6 & 0 & $t$ & 0 & 0 & 57 & 24 & 22 & 0 & 42 & 42 & 16 & \\
\hline $4-3,68-70$ & 2 & Zeolitic mud & 29 & 0 & 40 & 8 & 10 & 0 & 4 & 0 & 0 & 63 & 28 & 20 & 0 & 46 & 42 & 12 & \\
\hline $5-3,68-70$ & 3 & Pelagic clay & 0 & 3 & 47 & 12 & 10 & 0 & 4 & 0 & 0 & 31 & 25 & 21 & 18 & 31 & 52 & 17 & \\
\hline $7-1,68-70$ & 3 & Zeolitic mud & 0 & 0 & 49 & 16 & 16 & 0 & 0 & 0 & 13 & 1 & 13 & 4 & 0 & 1 & 94 & 3 & \\
\hline $8-3,68-70$ & 4 & Nannofossil chalk & 168 & 0 & 44 & 15 & 8 & 0 & 3 & 3 & 5 & 3 & 21 & 7 & 7 & 4 & 89 & 7 & \\
\hline $15-3,68-70$ & 5 & $\begin{array}{l}\text { Marly nannofossil } \\
\text { chalk }\end{array}$ & 235 & 0 & 23 & 6 & 18 & 0 & 0 & 0 & 0 & 5 & 30 & 0 & 11 & 5 & 95 & 0 & \\
\hline $21-3,68-70$ & 5 & $\begin{array}{l}\text { Marly nannofossil } \\
\text { chalk }\end{array}$ & 125 & 0 & 16 & 7 & 7 & 0 & 2 & 0 & 0 & 6 & 22 & 14 & 8 & 6 & 76 & 18 & \\
\hline $25-3,70-71$ & 5 & Carbonaceous shale & 0 & 0 & 125 & 15 & 6 & 6 & 4 & 17 & 0 & 3 & 11 & 8 & 0 & 3 & 88 & 9 & \\
\hline $27-3,32-33$ & 6 & $\begin{array}{l}\text { Marly nannofossil } \\
\text { chalk }\end{array}$ & 175 & 0 & 46 & 5 & 5 & 0 & 3 & 0 & 0 & 4 & 12 & 6 & 0 & 6 & 84 & 10 & \\
\hline $29-3,22-23$ & 6 & $\begin{array}{l}\text { Marly nannofossil } \\
\text { chalk }\end{array}$ & 140 & 17 & 63 & 9 & 10 & 0 & 2 & 0 & 0 & 6 & 17 & 7 & 0 & 6 & 88 & 6 & \\
\hline $31-3,114-115$ & 6 & Limestone & 237 & 0 & 31 & 6 & 5 & 0 & $\mathrm{t}$ & 2 & 0 & 7 & 20 & 10 & 7 & 8 & 81 & 11 & \\
\hline $34-3,22-23$ & 6 & Limestone & 235 & 4 & 8 & 1 & 0 & 0 & 0 & 0 & 0 & 3 & 11 & 4 & 6 & 6 & 88 & 6 & \\
\hline $37-3,27-28$ & 6 & Limestone & 275 & 13 & 17 & 5 & 7 & 0 & 3 & 0 & 0 & 4 & 20 & 11 & 8 & 4 & 84 & 12 & \\
\hline $39-3,66-67$ & 7 & $\begin{array}{l}\text { Calcareous carbon- } \\
\text { aceous shale }\end{array}$ & 120 & 46 & 34 & 12 & 9 & 2 & $\mathrm{t}$ & 2 & 0 & 5 & 9 & 0 & 0 & 21 & 79 & 0 & \\
\hline $41-3,75-77$ & 7 & $\begin{array}{l}\text { Calcareous carbon- } \\
\text { aceous shale }\end{array}$ & 185 & 19 & 52 & 12 & 2 & 0 & 5 & 0 & 0 & 27 & 12 & 0 & 0 & 50 & 50 & 0 & \\
\hline $42-3,57-58$ & 7 & Carbonaceous shale & 15 & 4 & 128 & 32 & 0 & 6 & 8 & 0 & 0 & 7 & 8 & 0 & 0 & 20 & 80 & 0 & \\
\hline $43-3,108-109$ & 7 & $\begin{array}{l}\text { Carbonaceous marly } \\
\text { dolomitic limestone }\end{array}$ & 60 & 285 & 19 & 0 & 3 & 0 & 0 & 0 & 0 & 11 & 2 & 0 & 0 & 73 & 27 & 0 & \\
\hline $45-3,23-25$ & 7 & $\begin{array}{l}\text { Carbonaceous } \\
\text { dolomitic limestone }\end{array}$ & 0 & 425 & 40 & 5 & 2 & 3 & 0 & 2 & 0 & 4 & 9 & 0 & 0 & 9 & 91 & 0 & \\
\hline $46-1,145-146$ & 7 & Dolomitic limestone & 0 & 397 & 38 & 5 & 0 & 2 & 0 & 0 & 0 & 14 & 10 & 0 & 0 & 30 & 70 & 0 & \\
\hline
\end{tabular}




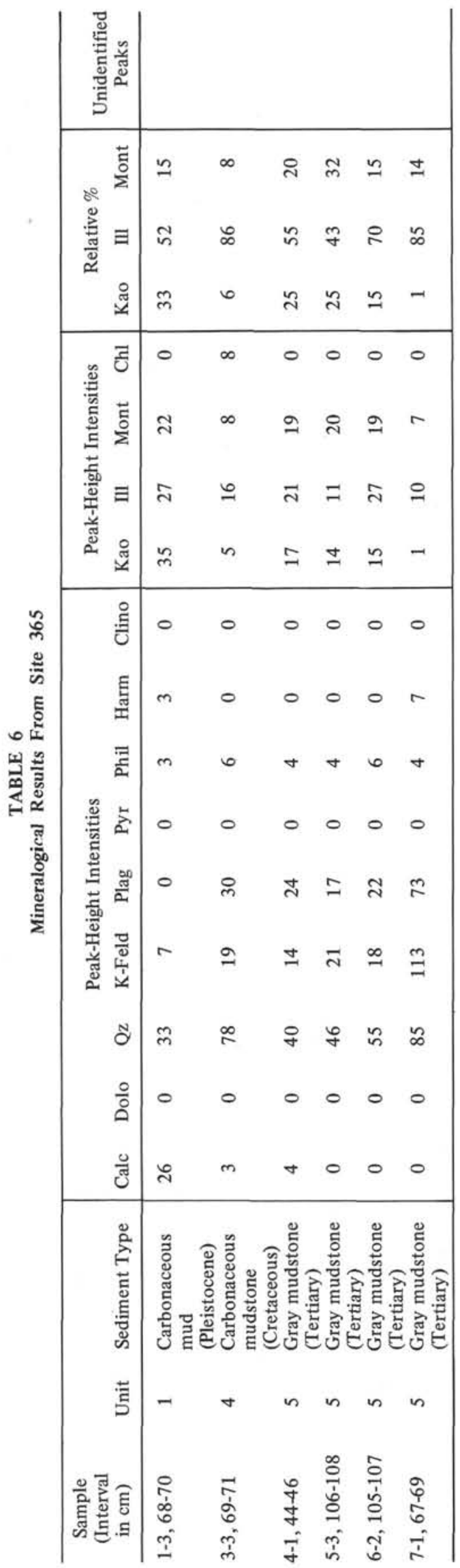

"Illite" is the term commonly used for $1 \mathrm{Md}$ mica found in sediments. Glauconite also has a $1 \mathrm{Md}$ or $1 \mathrm{M}$ structure and is very difficult to distinguish from illite by X-ray diffraction, especially in a mixture of minerals. Thus, the "illite" category listed in Tables 1-6 may also include amounts of mica and glauconite.

The relative abundance of each mineral in a threecomponent clay system (viz., kaolinite, "illite," and montmorillonite equal $100 \%$ ) may be expressed as a percentage following the method of Johns et al. (1954). The relative percentage of chlorite cannot be calculated in this manner without investigation at higher $2 \theta$ angles. The $17 \AA$ area measured for montmorillonite is taken as read, the $10 \AA$ area of illite multiplied by a factor of four, and the $7 \AA$ represented by kaolinite multiplied by a factor of two (Johns et al., 1954). These values are then converted to percentages (Tables 1-6).

\section{RESULTS}

\section{Site 360 (Table 1)}

The X-ray diffraction analyses of Site 360 sediments confirm the smear slide descriptions. Calcite is the overwhelmingly predominant mineral throughout (all the calcite at this and the other sites is the stable variety, low-magnesian calcite). Its relative abundance decreases towards the bottom of the hole (Cores 40-50), with a corresponding relative increase in terrigenous quartz and feldspar. Traces of phillipsite were noted throughout the cores (a trace [t] listed in Tables 1-6 means that the mineral was detected in the noncarbonate analysis, but not in the bulk analysis).

"Illite" predominates in the clays, with little significant variation in relative abundance down the hole. Kaolinite predominates over montmorillonite in the uppermost cores, but montmorillonite is more abundant than kaolinite in Cores 25 to 50 .

\section{Site 361 (Table 2)}

This site shows considerable variation in mineralogy. The terrigenous and calcareous muds and pelagic clays in the upper regions of the hole were chosen for X-ray analysis, and a variety of shales, sandy mudstones, and sandstones in the lower layers. Thus calcite varies from absent throughout much of the hole to abundant in Core 48 , where a calcite-cemented sandstone was Xrayed. Dolomite was noted only in Core 38. Pyrite is present in most of the cores from Cores 30-44. Phillipsite is detectable from Core 8 downward, and significant amounts occur in Cores 26-32 and 44-48. Cores 1 and 42 also contain harmotome.

Illite again dominates in the clays. Montmorillonite predominates over kaolinite from Cores 2-26, but montmorillonite is virtually absent in the lower cores, with only illite and kaolinite remaining. Montmorillonite is especially abundant in Cores 8 and 10 , being equal to or greater than illite in relative abundance.

\section{Site 362 (Table 3)}

These cores are predominantly calcite with minor amounts of dolomite and terrigenous material. 
Phillipsite is present in trace or minor amounts, as to a much lesser extent are harmotome and clinoptilolite. All three clay minerals are present throughout, with little recognizable variation in relative abundance.

\section{Site 363 (Table 4)}

As at Site 362 , this site is also dominated by carbonate minerals-chiefly calcite, but with dolomite increasing markedly from Cores 32-39. Clinoptilolite is common in Cores 15-29, and phillipsite and harmotome occur in minor quantities throughout, with phillipsite slightly more abundant in the lower half of the hole.

Dolomite encountered at this hole is best termed protodolomite (the "nonideal" dolomite of some authors). A protodolomite does not possess the ideal dolomite structure of a 1:1 molar $\mathrm{CaCO}_{3}-\mathrm{MgCO}_{3}$ ratio (see Goldsmith and Graf, 1958). Protodolomites differ from ideal dolomites by containing mole excess $\mathrm{CaCO}_{3}$ and by not having perfect ordering of the $\mathrm{Ca}$ and $\mathrm{Mg}$ atoms in the crystal structure. The ordered array of $\mathrm{Ca}$ and $\mathrm{Mg}$ atoms in dolomite produces X-ray "order reflections." The presence or absence of these reflection peaks and their relative intensities and sharpness enable a qualitative statement to be made concerning the ordering state.

Dolomites in this hole have a $d$-spacing of $2.896 \AA$ $2.900 \AA$ for the $(211)$ maximum, compared with $2.886 \AA$ for an ideal dolomite. Excess $\mathrm{CaCO}_{3}$ has caused an expansion of the crystal lattice, because $\mathrm{Ca}$ atoms are larger than the $\mathrm{Mg}$ atoms that they replace. The larger $d$-spacings correspond to approximately 54-56 mole \% $\mathrm{CaCO}_{3}$. The (100), (221), and (111) order-reflection maxima are absent, indicative of a poorly ordered protodolomite.

The clay mineralogy is also similar to Site 362 ; illite predominates, but all three clay groups are present throughout with little variation in abundance. Both kaolinite and montmorillonite appear to increase towards the bottom of the hole, while illite decreases.

\section{Site 364 (Table 5)}

A significant feature at Site 364 is the abundance of dolomite from Cores 29 to 46 . Dolomite intensities increase dramatically in Cores 43-46, and calcite, which is associated with dolomite in the upper cores, suddenly becomes absent in Cores 45-46.

Dolomite in the upper cores (29-41) is protodolomite (about 56 mole \% CaCO 3 ) similar to that at Site 363 . However, Core 43 contains more nearly ideal dolomite with about 53 mole $\% \mathrm{CaCO}_{3}$ and the appearance, albeit weak and diffuse, of ordering peaks. Cores 45 and 46 contain stoichiometric dolomite (Caso Mgso) and fairly sharp ordering peaks. Thus dolomite in this hole becomes more ideal, i.e., stoichiometric, with depth. It is well established that dolomites formed at higher salinities contain less excess $\mathrm{CaCO}_{3}$ in their lattices and are better ordered (Goldsmith and Graf, 1958; Füchtbauer and Goldschmidt, 1965; Marschner, 1968; and Supko et al., 1974). Supko et al. (1974) also found a progressive trend towards more ideal dolomite with depth in their Red Sea cores (DSDP Leg 23) as evaporite sequences were approached. Thus, the similar increase in better ordered, more stoichiometric dolomite in the lowest cores at Site 364 lends additional evidence for the inferred presence of an evaporite body in the Angola Basin.

Pyrite is slightly more common towards the bottom of this hole. Phillipsite is`the dominant zeolite and is present throughout most of the hole; harmotome and clinoptilolite are scattered sporadically throughout.

Illite is dominant in the clays, although kaolinite is very abundant in Cores 1-5 and again in Cores 39-46. Montmorillonite is subordinate throughout, and is not detectable in Cores 39-46.

Climate may account for the greater abundance of kaolinite in these cores in contrast to the relatively lower abundance in sites to the south. Kaolinite is known to be produced more abundantly in regions of tropical weathering-moist climate and good drainage favor the formation of kaolinite (Carroll, 1970). The Angolan sourceland today is certainly more humid and better drained than the South and South West African sourcelands, and this may explain the greater relative abundance of kaolinite in the upper cores.

\section{Site 365 (Table 6)}

These cores have a consistently greater terrigenous component than in those sites to the south. Phillipsite is common, and harmotome is noted in two cores. Clinoptilolite was not detected. Illite is the most abundant clay, with kaolinite predominating over montmorillonite, again probably reflecting tropical weathering.

\section{ACKNOWLEDGMENTS}

This project forms part of the work of the joint Geological Survey/University of Cape Town Marine Geoscience Unit. Both organizations are thanked for their support. The writers are grateful to Judy Chiddy, Colin Hartley, Susan Sayers, and Matthew Smith for assistance in sample preparation and analysis.

W.G. Siesser is presently a member of the C.S.I.R. National Research Institute for Oceanology; J.M. Bremner is a member of the Geological Survey.

\section{REFERENCES}

Carroll, D. 1974. Clay minerals: A guide to their X-ray identification: Geol. Soc. Am. Spec. Paper 126, 80 p.

Füchtbauer, H. and Goldschmidt, H., 1965. Beziehungen zwischen Calciumgehalt und Bidungsbedingungen der Dolomite: Geol. Rundschau, v. 55, p. 29-40.

Goldsmith, J.R. and Graf, D.L., 1958. Structural and compositional variations in some natural dolomites: J. Geol., v. 66, p. 678-693.

Johns, W.D., Grim, R.E., and Bradley, W.F., 1954. Quantitative estimations of clay minerals by diffraction methods: J. Sediment. Petrol., v. 24, p. 242-251.

Marschner, H., 1968. Ca-Mg distribution in carbonates from the Lower Keuper in NW Germany. In Miller, G. and Friedman, G.M. (Eds.), Carbonate sedimentology in central Europe: New York (Springer-Verlag), p. 33-38.

Supko, P.R., Stoffers, P., and Coplen, T.B., 1974. Petrography and geochemistry of Red Sea dolomite. In Ross, O.A., Whitmarsh, et al., Initial Reports of the Deep Sea Drilling Project, Volume 23: Washington (U.S. Government Printing Office), p. 867-878. 